\title{
A PSYCHOLOGICAL BASIS FOR THE ORIGIN OF RELIGION
}

\author{
BY A. J. SNOW
}

NORTHWESTERN UNIVERSITY

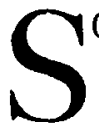

OME writers upon the subject maintain that the basis of religion is to be found in what they call "religious instinct" or "religious instincts." They have never made any serious attempt to explain what they meant by these particular instincts or instinct; in fact they never gave any fundamental proof of the above hypothesis. James rightly points out that to say that there is a religious love, religious fear, religious joy, etc., means nothing else than that the religious love is only an emotion of love directed toward religious objects. And the same thing is true of all other so-called "religious instincts." Because hardly any present psychologists accept the above theory, we are justified in dismissing it.

In order to determine the origin of religion we must put ourselves in the position of the primitive man who first gave it expression. Consequently, the first task before us is to attempt to describe the mental life of the primitive man. Religion being a product of the career of man, we must necessarily determine the psychological mechanism which brought it about. Are we to suppose that the perceptive experience of our forefathers was the same as ours? We, in our everyday experience, try to explain everything in terms of mechanical causation. Our representations are intellectual primarily, while the motor and emotional functions of our judgments are practically left out or are at their minimum. We have made the intellect the center of our perceptive experience. We do not want to believe that Santa Claus is the Christmas tree or the presents given on that occasion. Our representations have the same character as our perceptions, and since the one is cognitive, the other must also be cognitive. Our perceptions being intellectual, our experience must also be intellectual. On the other hand, the experience of the prehistoric man is altogether different. We may get most of the characteristics of primitive life by studying the mind of the child. A child's experience of a doll is not that of a wooden or painted being, but a being much like itself, which has the power to eat, cry, sleep, etc. When the child stumbles over a chair, it becomes angry with it and punishes it for being the cause of the child's tumbling over. The child knows 
that there is a "live principle" which is the very chair, very much like itself, which has the power to make it stumble. In a child's judgment, the emotional and motor experience is at a maximum, and the intellectual at a minimum. From the following examples we may note that the primitive man had the same sort of experience as the child has. For instance, the Cherokees believed that the birds lived in a civil society just as they did. They also thought that illness came from what we may call today mystic action exercised by animals on the hunters. Among the Mexicans each of the organs of the human body has a mystical significance, that may be illustrated by the custom of cannibalism. The heart, liver, etc., are imputed to have the same qualities for them that eat them as they had for the man from whose body they were taken. The religious practice that is known as mana may be cited in this conncction. "If a man has been successful in fighting, it has not been his natural strength of arm, quickness of eye, or readiness of resource that has won success, he has certainly got the mana of a spirit of some deceased warrior to empower him, conveyed in an amulet or a stone round his neck, or a tuft of leaves in his belt, in a tooth hung upon a finger of his bow hand, or in the form of words with which he brings supernatural assistance to his side. If a man's pigs multiply, and his gardens are productive, it is not because he is industrious and looks after his property, but because of the stones full of mana for pigs and yams that he possesses. Of course, a yam naturally grows when planted, that is well-known, but it will not be very large unless mana comes into play; a canoe will not be swift unless mana be brought to bear upon it." Or we may call to our attention the famous example of the camel sacrifice by the Arabs, the significant factor of this sacrifice being "the conveyance of the living blood to the godhead, and the absorption of the living flesh and blood into the flesh and blood of the worshippers." 2 Primitive men made no distinction between animate and inanimate objects, as stones, trees, etc.; they held that plastic images of objects are as real as the objects themselves. Chinese regard the images of objects as altered egos or an indwelling soul. They associate the image with the object, and that is so strong that it becomes the basis of what we call idolatry. The Mandans of North America believe that the pictures are as living as their models. The primitive Indians refused to have a picture taken because they thought that it would give the man who had the

1 R. R. Marett, The Conception of Mana, p. 48.

' Robertson Smith, Lectures on the Religion of the Semites, p. 339. 
picture a power over them. Primitive people regard the names as real and secret and, in fact, as a vital part of them; just as much a part of their individuality as their eyes or teeth. They think they would suffer for the abuse of their name as they would from a wound inflicted on their body. From the West African Indians we are informed that there is a real physical connection between a man and his name. Therefore, the king's name is not given away, and the same is found to be true with the early Jews; they substituted a name for the real name of their God because they believed that a person may hurt the God by misuse of His real name. The primitive man believed that whatever attached to one's shadow attached to one's self; to walk on one's shadow would be mortal injury. Among West Africans, a murderer is the individual who thrusts a knife in the shadow of a man, and if the guilty person is caught, he is executed. Man in this stage of mental development interprets dreams as actual perception, just as real as the activities of waking life. Dreams are even regarded as sacred things, and God is thought to reveal himself to men that have them. ${ }^{3}$

From these few examples we may infer that the representations of a primitive man are of a volitional and emotional nature. That does not mean that the primitive man was in any sense different from what we are today.4 Human nature has changed very little, as an organic mechanism. The difference is not in the human organism that man inherits today, but in the ages of learning, science and tradition. Cultured people aim to suppress the emotional and volitional elements, especially in the training of children. We take interest in having the intellectual or cognitive factors outstanding; while in the primitive man the logical elements are not as highly developed and therefore the primary functions in his judgments are volitional and emotional, and as a consequence of that, things are interpreted, i. e., experienced by him, altogether differently from what they are by us.

What is the world of objects to the primitive mind as he experiences it? From the above illustrations and analysis we may suppose that the primitive mind does not recognize the external world; the whole world in a certain sense is a part of him, being in some way vitally connected with his actual personality.

- Most of these examples are taken from Levy Bruhl, Les fonctions mentales dans les sociétés inférieures, Paris, 1910.

As Dewey points out in his Reconstruction in Philosophy, p. 4. (Henry Holt \& Co., 1920.) 
We may assume, what is an obvious fact, that the primitive mind lacked the conception of mechanical causation. Even in our cultured life we lack some of the causal explanations, and some of us, nay, most of us, try to explain the occurrence of some phenomena by supernatural causes. Is not our literature, even contemporary literature, full of magic? The savage may be familiar with mechanical causation in so far as it concerns his small sphere of personal interests, but he does not, we are sure, employ that principle in reference to everything in the world about him. We may say that the blowing of the wind, the crash of the thunder, the flash of lightning, the flowing of the rivers, the fall of bodies toward the earth, rain, fire, heat and light from the sun, growth of vegetation, reproduction, growth of animals, and complete darkness, all these things interest him otherwise than they do us. In all of these he either sees pain or pleasure; in respect to them he is in a state of fear and awe, or, as Warde Fowler called it, in a state of religio, in a state of intense feeling. To relieve himself of this state of religio, which is necessary in order to make life stable, in order to make it possible for him to predict about the future, to avoid pain-giving experiences, and to multiply his pleasures, he must make some account of the things about him. The only kind of causation he is aware of, because of the predominance of the volitional and emotional factors, is his act of volitional response from these feelings, emotions, and desires, and this naturally becomes the model for him upon which he bases his ideas in interpreting the world. This is preserved in his memory, is lived over and over again as often as the memory is revived. Each new revival takes new form and fancy. The interest of the moment selects the incidents of the past as stored in the memory, and shapes them into fantastic revivals of past experiences. As Dewey points out, the primitive man's leisure, occupying by far the larger part of his waking life, and being devoid of contemplation of the future, is filled up with fanciful recollections of the past. These recollections are emotional and volitional, and take the form of a drama. It is this dramatic form into which recollections are shaped that becomes all-important and interesting. The experiences are not only dramatized, but also personified. Each experience, each individual factor or member of an experience, as told and retold in time of leisure, is an expression of some personal purpose. Every object or individual that took part in any experience, becomes personified and its activity is explained in terms of purposes, desires, hopes or fears. Each object not only lives an individual life of a person, but 
a life of emotions and volitions, of pain and pleasures, of love and hate, of triumphs and defeats. Primitive man finds in them important factors influencing his own life, in fact indispensable factors of his situations, and therefore they become, whether animate, or inanimate, members of his "world" or his tribe, or his ancestry. And the objects of his experience, become members of his community, tribe, family, or of his enemy, have certain powers or influences over his destinies.

Now, may we be able to see what may have been the bases which gave rise to religion in such a primitive world of experience. The flash of lightning, the noise of thunder, the destructive power of the flood, the activities of a tiger, are the factors which in primitive man excite his emotion of fear, while other incidents again excite his other emotions. For the sake of illustration and clearness we may take a concrete example: when the man of the stone age went out with his fellow men to hunt and after a time a storm came up and his fellow men happened to get killed by the fall of a tree, or a bolt of lightning, he probably trembled with fear and ran back to his house, knowing that there was some external cause which was responsible for the death of his tribesmen. Now let us suppose that at some other time, the lightning, or some other factor happened to kill a deer which he was chasing. He probably felt a joy because again he knew that it was not he who killed the deer. But he did not stop to think of the reasons for these particular happenings. At another time, when he desires to cross a stream in company with other men, some of them happen to get drowned and others cross safely. This experience again awakens in him a sense of fear and also a joy because he happened to cross safely - an experience which he does not explain, because the primitive man's judgments are not cognitive; i. e., he does not interpret his experiences in terms of mechanical causation, neither does he see the connection nor connect the past experiences with the present. His past experience assuming a dramatic form, does not lend itself to that end. He is just like a child who at one moment sticks pins in her doll, pulls its hair, throws it about, and the next moment is giving it her greatest attention by feeding it, dressing it as a mother does a child. The above experience of the primitive man is just a matter of fact with which he does not associate any mechanical motion.

With the development of language, man not only dramatizes his experiences of the past, which he tells in the form of a story, but also, 
that which seemed to him strange and unknown now begins to be interpreted, and to assume teleological meaning. In order to be relieved of the state of religio, he begins to interpret these objects, developing different kinds of hypotheses concerning them, and probably by analogy, even though unconsciously, he develops a hypothesis which is supposed to explain everyday experience. In that stage of development the savage knows that by doing good deeds to his fellow men they in turn are kind and helpful to him and vice versa. He probably thinks the same is true with the objects about him. That is, if he would please these powers, or objects personified, they would in turn be helpful to him. He therefore assumes that all natural evil is due to his indifference or displeasing actions to these forces.

Not only is the world about him personified, and the motivating force teleological, but there devclops a system of explanations and predictions. This "system" of explanations and predictions not only makes life more pleasant and stable, but relieves men from the intense state of feeling, called religio. His explanations are not mechanical but dramatic and personal. Naturally, men did not check their fancies by fact; the explanations of the happenings took the form of supernaturalism, rather than of naturalism. In this stage of development, man becomes conscious of his limitations in his battle for food and against environment in general; he finds in them forces which are stronger than himself, and which are the determining agents of his success or failure in this struggle. And so, through his fear and trembling he learns how to avoid giving offense to these fearful powers. From the analogy of his attitude toward his fellowmen, he hopes that by avoiding their anger, they will help him to accomplish his end; he develops a certain definite way by which he can serve and please these agents. And therefore we find him bargaining with these powers by praying and offering sacrifices to them, and here we find the beginning of religion at work.

We may summarize our discussion in the following paragraph. Primitive men develop a system of explanations which are a means of relieving them of an intense state of complex feeling, and insecurity, and giving them not only clarity and stability, but also a power of prediction, even though it be not accurate. Because their experience is retold dramatically, and their material is organized not logically but emotionally, the objects of their experience become personified. The world about them assumes a multiplicity of living personalities, very much like themselves, some having definite controlling powers 
over their aims and desires. The explanation of the world is that of fancy and not of fact, of poetry and not of science, of poetic truth and not of scientific fact; a world of supernaturalism, and not of naturalism. In that world they learn how to please the powers that control them; the instruments that they develop are those of magic, rather than those of scientific method. It may be added that when man has in the course of development learned that mechanical science makes prediction more certain than magic, supernaturalism as an institution loses its place as an instrument of control of natural events, and becomes a social instrument, losing that function with the growth of secular organizations, whose chief function is to provide social mechanism. Again institutionalized supernaturalism becomes the great inspirer of art in every form, only to lose that place with the development of Protestantism.5 Here we may pause to express regret, because of the loss to art, as such, and to humanity involved in the decline of supernaturalism as an inspiration of the esthetic imagination.

- We must not be misunderstood to mean that these transitions were abrupt. In fact, all these tendencies are to be found at any given time, but one or the other of these dominate at different historic periods. 